\title{
Service Communication on Unisba Student Satisfaction During the Covid-19 Pandemic
}

\author{
${ }^{1}$ Tresna Wiwitan, ${ }^{2}$ M. Subur Drajat, ${ }^{3}$ Nurrahmawati \\ ${ }^{1,2,3}$ Fakultas Ilmu Komunikasi Universitas Islam Bandung, Jl. Tamansari no. 24-26, Bandung, Indonesia. \\ Email: 'tresnawiwitan1803@gmail.com, ${ }^{2}$ nurrahmawati10@gmail.com, ${ }^{3}$ msuburdrajat@gmail.com
}

\begin{abstract}
One of the indicators of stakeholder assessment of higher education institutions is the service factor provided by the institution. Online lectures and lecturer services - educators to students - are part of the communication services that Unisba provides to its students. Student dissatisfaction with the services that faculties and universities provide is usually conveyed on social media and it can be a boomerang effect for Unisba. Customer Relationship Management (CRM) is a form of service communication that is based on building relationships with customers. The purpose of this study was to determine and analyze the effect of service communication on student satisfaction. This study uses quantitative analysis method to test the influences. The population is Unisba strata-1 (S1) active students in the 2020/2021 academic year, totaling 12,854 students. To determine the sample size, the authors used the Slovin formula with a margin of error of 0.09 and the number of samples is 132 students. The sampling technique that the authors used was the stratified probability one. The data analysis that we used was simple linear regression to see the influence of people, process, and technology aspects on Unisba student satisfaction. The research results show that human, process, and information technology aspects have a significant influence on Unisba student satisfaction.
\end{abstract}

Keywords: Customer Relationship Management, service communication, student satisfaction, pandemic Covid-19.

\section{INTRODUCTION}

Since the Covid-19 pandemic at the beginning of March 2020, the Minister of Education and Culture of the Republic of Indonesia issued Circular Letters number 2 and 3 of 2020 regarding the Prevention and Handling of Corona Virus Disease (Covid-19). The Rector of the Islamic University of Bandung (Unisba) responded to this by issuing a circular no. 198 dated 28 March 2020 to stop all face-to-face lecture activities and require lecturers to carry out online lectures. Unisba as an Islamic university must be able to develop the values of the Islamic spirit through the Tridarma of Higher Education, because these values are the basis of all supporting knowledge and skills that penetrates every life, including service communication (Effendi \& Setiadi, 2021). And all of this has an impact on the service communication carried out by lecturers and education staff to students.

Service communication provided by lecturers and teaching staff to students during this pandemic is one of the important indicators, where this communication is not carried out faceto-face but can be done virtually. Online lectures through e-kuliah.unisba are one of the communication services carried out by Unisba for students. Online lectures or remote learning are one of the solutions and effective learning models during a pandemic (Afriliana et al., 2021) The 
ekuliah.unisba system had several times encountered problems, at the beginning of the odd semester of the 2020/2021 academic year, it often had server downs, and even at midterm exam it had the same so that lecturers and students were not very comfortable using it.

This research is not only related to the service communication of ekuliah. unisba but also with the ways in which lecturers and teaching staff provide services outside the context of academic issues. Service communication is a communication practice in supporting the provision of the best service to the customers of an organization in order to create a harmonious relationship of mutual understanding. Currently, the development of the era leads to openness, globalism, and democracy. The old paradigm in government and private organizations which relies on authority and tends to ignore the quality and quantity of services should be abandoned.

\section{Customer}

Relationship

Management (CRM) is a corporate level strategy that focuses on maintaining customer relationships. Service communication (Saleh, 2010) is a communication practice in supporting the provision of the best service to the customers of an organization in order to create a harmonious relationship of mutual understanding, therefore, it may help an organization to achieve its objectives. The concept of CRM has been used in various service communication research. This CRM concept is the basis of this research, seen from the indicators of people, process, and technology on student satisfaction as customers from the university. Based on these problems, this study aims to identify and analyze: 1) the influence of the people aspect on Unisba student satisfaction, 2) the influence of process aspect on Unisba student satisfaction, and 3) the influence of the technology aspect on Unisba student satisfaction.

The concept of Customer Relationship Management (CRM) has been used in various research on service quality. According to Francis Buttle (Saleh, 2010) customer relationship management is a core strategy in business that integrates internal processes and functions with all external networks to create and deliver value for target customers profitably.

Francis Buttle explained that Customer Relationship Management (CRM) can be studied from three levels, namely:

1. Strategic CRM is a 'top-down' view of CRM as the most important business strategy that puts customers first and aims to attract and retain profitable customers.

2. Operational CRM, is a view of CRM that focuses on automation projects such as service automation.

3. Analytical CRM is a 'bottomup' view of CRM that focuses on extracting customer data for strategic and tactical purposes. (Saleh, 2010)

Strategic CRM focuses on efforts to develop a customer-oriented business culture. This culture is intended to win hearts and maintain customer loyalty.

Kotler (Rustanta \& Setyawati, 2019) defined satisfaction as a feeling of pleasure or disappointment that came from a comparison between one's perception of the results of a product and its expectations. If the product performance from experience is below expectations, it is dissatisfied, if the same, it is satisfied, and if above, it is highly satisfied. The consequence of this definition is that the measurement of satisfaction is based on the gap between expectations and experience, without having to question the dimensions of the indicators that are used as a measure of customer satisfaction. Kotler asserted that satisfaction is one's feelings of 
pleasure or disappointment that arise after comparing the thought performance with the expected performance. In practice, customer satisfaction is not only influenced by service factors, but also other factors. It's just that the service factor is the main factor in determining customer satisfaction (Kasmir, 2017).

\section{METHOD}

The research method that we used in this study was an explanatory survey. We chose this method based on the consideration that this method would not only provide empirical facts on site but also explain the effect analysis. The explanatory survey method predicts research results, the relationship between variables based on a rational relationship (Bajari, 2015). This method is concerned with discussing the effects of research variables by testing research hypotheses as well as explaining relationships, and making predictions and implications. The explanatory survey method is explanatory, that is, in addition to collecting data through questionnaires, trying to test the effects of the variables studied, it also explains the causal relationship between the variables through hypothesis testing (Suryana et al., 2019).

The population in this study were Unisba undergraduate students who were actively studying, totaling 12,854 students (Unisba Psitek, 2020). To determine the sample size we used the Slovin formula, with an error tolerance limit of 0.09 and the sample size in this study amounted to 132 students. The sampling technique we used was proportional strata with the aim of having student representatives from all faculties at Unisba. The data collection technique used a questionnaire, observation, interviews, and literature study. The data analysis that we used was a regression test design, intended to test the influence of the $\mathrm{X}$ variable $(\mathrm{X} 1, \mathrm{X} 2$, and $\mathrm{X} 3$ ) on the $\mathrm{Y}$ variable. This design is used to see the big or small differences in the influences of variables $\mathrm{X} 1, \mathrm{X} 2$, and $\mathrm{X} 3$ on the $\mathrm{Y}$ variable. Simple linear regression is based on a functional or causal relationship of one independent variable $(\mathrm{X})$ with one dependent variable (Y) (Tjia \& Fitriani, 2019). In the context of this research, simple linear regression was used to see the influence of people, process, and technology aspects on Unisba student satisfaction. According to Burhan Bungin (Bungin, 2017) in the book "Quantitative Research Methodology" (2017:222), to test H0 the design analysis model is used as follows:

$$
Y=\beta 0+\beta 1 X 1+\beta 2 X 2+\beta 3 X 3
$$

Based on this design, the regression test design model is as follows: $\mathrm{X} 1=$ people, $\mathrm{X} 2$ = process, $\mathrm{X} 3=$ technology, and $\mathrm{Y}=$ Student Satisfaction.

TABLE 1. People Indicator

\begin{tabular}{llcccccc}
\hline No & \multicolumn{1}{c}{ Statement } & $\begin{array}{c}\text { SS } \\
\%\end{array}$ & S & TAP & TS & STS & $\begin{array}{c}\text { TOTAL } \\
\text { SCORE }\end{array}$ \\
\hline 1. & Lecturers are enthusiastic about giving online lectures & 3 & 54.5 & 22.7 & 19.7 & 0 & 100 \\
2. & Lecturers are enthusiastic about doing online lectures & 3.8 & 52.3 & 24.2 & 19.7 & 0 & 100 \\
3. & Lecturers are able to operate ekuliah.unisba.ac.id & 10.6 & 65.2 & 14.4 & 9.1 & 0.8 & 100 \\
4. & Lecturers are able to operate ekuliah.unisba.ac.id & 7.6 & 54.2 & 17.4 & 18.2 & 2.3 & 100 \\
5. & Lecturers are able to evoke a lecture atmosphere & 1.5 & 24.2 & 33.3 & 36.4 & 4.5 & 100 \\
6. & Staff is able to provide excellent service & 7.6 & 53.8 & 22.7 & 14.4 & 1.5 & 100 \\
7. & Staff is ready to provide services & 6.8 & 56.1 & 22.7 & 14.4 & 0 & 100 \\
8. & Lecturers and staff are friendly in providing services & 10.6 & 80.3 & 6.8 & 2.3 & 0 & 100 \\
\hline
\end{tabular}

$\mathrm{SS}=$ Strongly Agree, $\mathrm{S}=$ Agree, $\mathrm{TAP}=$ No Opinion, $\mathrm{TS}=$ Disagree, $\mathrm{STS}=$ Strongly Disagree 


\section{RESULT AND DISCUSSION}

\section{People Indicator (Human)}

The people indicator consists of a measure of enthusiasm and friendliness, questions no. $1-2$ are for measuring enthusiasm, where most of the respondents answered agrees. Questions no. $3-7$ are for measuring ability, where most of the respondents answered agrees, except for measuring the ability of lecturers to evoke a lecture atmosphere, only $24.2 \%$ of respondents agreed. It means that 32 of 132 respondents agreed. During a pandemic like this, where lectures are conducted online, lecturers are required to be more creative in giving lectures. Lectures may be done by using the Zoom platform, creating lecture modules, or making lecture videos to be uploaded to e-lectures or on Youtube. Assignments for students are not structured ones but can be analyzed by analyzing current cases. Question no. 8 is for measuring friendliness on the people indicator, $80.3 \%$ agreed.

TABLE 2

\begin{tabular}{lll}
\multicolumn{3}{c}{ Variables Entered/Removed $^{\mathbf{a}}$} \\
\hline Model & $\begin{array}{l}\text { Variables } \\
\text { Entered }\end{array}$ & Variables Removed \\
& Method \\
\hline 1 & Var_X1_- $^{\text {People }}$ & Enter \\
& & \\
\hline $\begin{array}{l}\text { a. Dependent Variable: Var_Y_Satisfaction } \\
\text { b. All requested variables entered. }\end{array}$ &
\end{tabular}

The regression method used is the enter method, which is to enter all predictors at once.

In the adjusted R Square column, the score is 0.346 . This figure shows how much the independent variables are able to explain changes in the dependent variables. The value of $\mathrm{R}$ Square means that $35.1 \%$ change in the $\mathrm{Y}$ variable (Student Satisfaction) is influenced by the X1 Variable (People Indicator). The variation of the independent variable used in the model (variable X1) is able to explain $35.1 \%$ of the variation in the dependent variable. Meanwhile, the remaining $64.9 \%$ is influenced or explained by other variables that are not included in this research model.

In the TABLE 4, the F-value is 70.176 and the significance is 0.000 . The conclusion is that the variable X1 (People Indicator) has an influence on variable $\mathrm{Y}$ (Student Satisfaction).

The TABLE 5 shows that the $\mathrm{t}$-value of the $\mathrm{X} 1$ variable is 8.377 and the significance value is 0.000 . It means that the $\mathrm{X} 1$ variable (People Indicator) has a significant influence on the $\mathrm{Y}$ variable.

The description above shows that the regression equation for the influence of the $\mathrm{X} 1$ variable on the $\mathrm{Y}$ variable can be described as follows:

\section{$Y=12.198+0.562 X 1$}

\section{Regression Equation Analysis:}

If the variable X1 (Human aspect) increases, the variable $\mathrm{Y}$ (Student Satisfaction) does the same. The indicators that influence the most are: enthusiasm, ability to complete work, friendliness of lecturers and educators in providing service communication.

The results of statistical tests show that there is an influence of the people (lecturers and educators) aspect on student satisfaction in service communication during the pandemic. Indicators of enthusiasm, ability to complete work,

TABLE 3

Model Summary ${ }^{b}$

\begin{tabular}{|c|c|c|c|c|c|}
\hline Model & $\mathrm{R}$ & R Square & $\begin{array}{l}\text { Adjusted R } \\
\text { Square }\end{array}$ & $\begin{array}{l}\text { Std. Error of } \\
\text { the Estimate }\end{array}$ & Durbin-Watson \\
\hline 1 & $.592 \mathrm{a}$ & .351 & .346 & 3,511 & 1,789 \\
\hline
\end{tabular}


TABLE 4

ANOVA $^{\mathrm{a}}$

\begin{tabular}{|c|c|c|c|c|c|c|}
\hline Model & & Sum of Squares & $\mathrm{Df}$ & Mean Square & $\mathrm{F}$ & Sig. \\
\hline \multirow[t]{4}{*}{1} & Regression & 864,945 & 1 & 86 & 70,176 & $.000^{\mathrm{b}}$ \\
\hline & & & & .945 & & \\
\hline & Residual & 1.602 .298 & 130 & 12,325 & & \\
\hline & Total & 2.467 .242 & 131 & & & \\
\hline
\end{tabular}

a. Dependent Variable: Var_Y_Satisfaction

b. Predictors: (Constant), Var_X1_People

friendliness of lecturers, and teaching staff in providing service communication during a pandemic has an influence on Unisba student satisfaction. In response, there are still student opinions that lecturers and teaching staff are less enthusiastic and less friendly in providing service communication to students. Interestingly only a few respondents stated that the lecturers were able to evoke the atmosphere of the lectures.

People indicator in service communication during a pandemic; teaching staff and lecturers become frontliners and the main factor in managing relationships with students and stakeholders. Lecturers must be proactive in growing student motivation in taking online lectures and teaching staff must have the ability to approach personally and professionally in providing services to students. In case of problems, lecturers and staff must persuasively give solutions, not be provocative, not blame others so that they can touch the hearts of the public. When dealing with an unsympathetic public, in Islam, deal with it persuasively qaulan layyinan, which is to speak gently and not rudely. With qaulan layyinan, the hearts of people or the public who are invited to communicate will be touched and their souls are moved to receive communication messages. Therefore, Unisba must continuously provide excellent service training to teaching staff and lecturers in an effort to instill awareness and values to teaching staff about the importance of providing the best service to students and stakeholders; it is not only a job but also part of worship related to humans (habluminanas). Unisba must educate the academic community (lecturers and teaching staff) about the concept of service communication as part of the stakeholder assessment of the image of Unisba (Wiwitan \& Yulianita, 2017). In addition, improving the quality of lecturers and teaching staff must be Unisba's future target through various improvements in research and community service, writing scientific articles in reputable journals, and increasing the competence of educators. To create an atmosphere of online lectures, the main keys are technology and creativity; technology helps lecturers and students improve their ability to access quality learning. Lecturers are required to be more creative and innovative in the learning process, not only making lecture

TABLE 5

\section{Coefficients $^{\mathrm{a}}$}

\begin{tabular}{clccccc}
\hline Model & & \multicolumn{2}{c}{ Unstandardized } & Standardized & & Sig. \\
& & Coefficients & Coefficients & T & B \\
& & B & Std. Error & Beta & & .000 \\
\hline \multirow{2}{*}{1} & (Constant) & 12,198 & 2,156 & & 5,658 & .000 \\
\hline
\end{tabular}

a. Dependent Variable: Var_Y_Satisfaction 
TABLE 6. Process Indicator

\begin{tabular}{|c|c|c|c|c|c|c|c|}
\hline No. & Statement & $\begin{array}{l}\mathrm{SS} \\
\%\end{array}$ & $\begin{array}{l}\mathrm{S} \\
\%\end{array}$ & $\begin{array}{c}\text { TAP } \\
\%\end{array}$ & $\begin{array}{l}\text { TS } \\
\%\end{array}$ & $\begin{array}{c}\text { STS } \\
\%\end{array}$ & $\begin{array}{l}\text { TOTAL } \\
\text { SCORE }\end{array}$ \\
\hline 1. & $\begin{array}{l}\text { Lecturers have the ability to communicate when giving } \\
\text { lectures and online consultations. }\end{array}$ & 12.1 & 71.2 & 9.8 & 6.8 & 0 & 100 \\
\hline 2. & $\begin{array}{l}\text { Teaching staff have the ability to communicate when } \\
\text { providing services online }\end{array}$ & 6.8 & 72.7 & 15.2 & 5.3 & 0 & 100 \\
\hline 3. & Lecturers and teaching staff are quick to respond. & 4.5 & 46.2 & 27.3 & 21.2 & 0.8 & 100 \\
\hline 4. & $\begin{array}{l}\text { Lecturers and teaching staff provide flexible policies in } \\
\text { case of problems. }\end{array}$ & 14.4 & 54.5 & 15.9 & 13.6 & 1.5 & 100 \\
\hline 5. & Lecturer gives objective assessment & 8.3 & 55.3 & 25 & 10.6 & 0.8 & 100 \\
\hline 6. & Lecturers give an assessment as expected & 13.6 & 62.1 & 17.2 & 5.3 & 1.5 & 100 \\
\hline 7. & Unisba provides compensation for online tuition quota & 9.1 & 43.2 & 21.2 & 15.2 & 11.4 & 100 \\
\hline 8. & Unisba gives tuition discount & 10.6 & 56.8 & 17.4 & 6.8 & 8.3 & 100 \\
\hline 9. & Unisba provides the best service & 6.1 & 51.5 & 28 & 10.6 & 3.8 & 100 \\
\hline
\end{tabular}

$\mathrm{SS}=$ Strongly Agree, $\mathrm{S}=$ Agree, $\mathrm{TAP}=$ No Opinion, $\mathrm{TS}=$ Disagree, $\mathrm{STS}=$ Strongly Disagree

materials using Power Points but also making lecture modules, making learning videos that are not only uploaded to e-lectures but also uploaded to Youtube so that they are easily accessible by students. In line with Jufandi Wuri's research on Public Services in the Covid-19 era, improving public service communication can be achieved by trying to operate all available resources, including financial, physical, and human resources (HR), organization, technological capabilities, and knowledge systems (Wuri, 2021). With high employee commitment in learning and training, supported by a strong corporate culture, employees will contribute to shaping the character of quality human capital (Madiawati et al., 2020).

\section{Process Indicator}

Process indicator consists of measuring tools for communication skills, complaint management, and rewards. Questions about communication skills consist of questions $1-2$, most of the respondents agree. The ability to handle complaints is represented by questions $3-4 ; 46.2 \%$ of respondents agree that lecturers and teaching staff are quick to respond to complaints, lecturers must open communication with students, especially during a pandemic where lecturers cannot meet face to face with students. And some respondents provide flexible policies in case of problem. The measuring instrument for giving rewards consists of questions no. 5 - 9, some respondents agree that lecturers and staff provide rewards, $43.2 \%$ of respondents agree that Unisba provides quota compensation for online lectures.

The regression method used is the enter method, which is to enter all predictors at once.

TABLE 7

Variables Entered/Removed ${ }^{\text {a }}$

\begin{tabular}{llll}
\hline Model & $\begin{array}{l}\text { Variables } \\
\text { Entered }\end{array}$ & $\begin{array}{l}\text { Variables } \\
\text { Removed }\end{array}$ & Method \\
\hline 1 & Var_X2 & & Enter \\
& Process $^{\mathrm{b}}$ & & \\
\hline
\end{tabular}

a. Dependent Variable: Var Y Satisfaction

b. All requested variables entered.

In the adjusted R Square column, the score is 0.498. This figure shows how much the independent variables are able to explain changes in the dependent variables. The value of $\mathrm{R}$ Square means that $50.2 \%$ change in the $\mathrm{Y}$ variable (Student Satisfaction) is influenced by the X2 Variable (Process Indicator). The variation of the independent variable 
TABLE 8

Model Summary ${ }^{b}$

\begin{tabular}{|c|c|c|c|c|c|c|c|}
\hline Model & $\mathrm{R}$ & R Square & \multicolumn{2}{|c|}{ Adjusted R Square } & \multicolumn{2}{|c|}{ Std. Error of the Estimate } & Durbin-Watson \\
\hline 1 & $.708^{\mathrm{a}}$ & .502 & \multicolumn{2}{|c|}{.498} & \multicolumn{2}{|l|}{3,075} & 1,993 \\
\hline \multicolumn{8}{|c|}{$\begin{array}{l}\text { a. Predictors: (Constant), Var_X2_Process } \\
\text { b. Dependent Variable: Var_Y_Satisfaction }\end{array}$} \\
\hline \multicolumn{8}{|c|}{$\begin{array}{l}\text { TABLE } 9 \\
\text { ANOVA }^{\text {a }}\end{array}$} \\
\hline Model & & & $\begin{array}{l}\text { of } \\
\text { ares }\end{array}$ & $\mathrm{Df}$ & Mean Square & $\mathrm{F}$ & Sig. \\
\hline \multirow{3}{*}{1} & Regre & & .015 & 1 & 1238.015 & 130,929 & $.000^{\mathrm{b}}$ \\
\hline & Resid & & .227 & 130 & 9,456 & & \\
\hline & Total & & 242 & 131 & & & \\
\hline
\end{tabular}

a. Dependent Variable: Var_Y_Satisfaction

b. Predictors: (Constant), Var X2 Process

used in the model (variable X2) is able to explain $50.2 \%$ of the variation in the dependent variable. Meanwhile, the remaining $49.8 \%$ is influenced or explained by other variables that are not included in this research model.

In the TABLE 9, the F-value is 130.929 and the significance is 0.000 . The conclusion is that the $\mathrm{X} 2$ variable (Process Indicator) has an influence on Y variable (Student Satisfaction).

The TABLE 10 shows that the $\mathrm{t}$-value of the $\mathrm{X} 2$ variable is 11.442 and the significance value is 0.000 . It means that the X2 variable (Process Indicator) has a significant influence on the $\mathrm{Y}$ variable (Student Satisfaction).

The description above shows that the regression equation for the influence of the X2 variable (Process Indicator) on the Y variable (Satisfaction) can be described as follows:

$Y=7.865+0.681 X 2$

\section{Regression Equation Analysis:}

If the X2 variable (Process Indicator) increases, the $\mathrm{Y}$ variable (Student Satisfaction) does the same.

It means that process indicator in service communication during a pandemic affects Unisba student satisfaction. The factors of communication skills, complaint management, and rewards by lecturers affect student satisfaction.

The process is a system or procedure that helps lecturers and staff to be able to establish good relations with students. Private university policies must be able to support the implementation of CRM in service communication activities; The stages of the CRM process include: a) Identification: Unisba must have a strong enough analysis through research conducted by academics or BPM on service communication activities during a pandemic. 2) Differentiation is the process of sorting students

TABLE 10

Coefficients $^{\mathrm{a}}$

\begin{tabular}{|c|c|c|c|c|c|c|}
\hline \multirow[t]{2}{*}{ Model } & & \multicolumn{2}{|c|}{$\begin{array}{c}\text { Unstandardized } \\
\text { Coefficients }\end{array}$} & \multirow{2}{*}{$\begin{array}{c}\text { Standardized } \\
\text { Coefficients } \\
\text { Beta }\end{array}$} & \multirow[t]{2}{*}{$\mathrm{T}$} & \multirow[t]{2}{*}{ Sig. } \\
\hline & & $\mathrm{B}$ & Std. Error & & & \\
\hline \multirow{2}{*}{1} & (Constant) & 7,865 & 1,959 & & 4,014 & .000 \\
\hline & Var_X2_Process & .681 & .060 & .708 & 11,442 & .000 \\
\hline
\end{tabular}

a. Dependent Variable: Var_Y_Satisfaction 
based on demographics, behavior, and expectations. Service communication must be based on the study program or faculty because the interests and policies of each study program or faculty are different. Complaints from students regarding e-kuliah. unisba can be collected, analyzed, and evaluated so that it will provide a more comprehensive picture of student needs. 3) Interaction (communication): establish continuous interaction with students. Communication can be made directly (personal and group communication) or using social media, such as Whatsapp groups, Instagram, Twitter, or Facebook. (Kriyantono, 2014) explained one of the principles of communication in Islam is qaulan balighan, namely using words that are effective, targeted, communicative, easy to understand, straight to the point. Lecturers and teaching staff should communicate using publicly understood language according to their intellectual level of the communicants. "Speak to people according to the level of their intellectuality!" (Hadith narrated by Muslim)
Social media during a pandemic has become one of the media for information and education, from the abundance of information and interaction opportunities to directions for the development of information (Sampurno et al., 2020). This means that social media is used as one of the communication media for Unisba services during the covid-19 pandemic.

Based on on-site data, there are several complaints from students against the services of lecturers and teaching staff; based on research on the Influence of Complaint Management on Student Trust, reliabilities of communication and complaint management will affect student trust (Indriyani \& Mardiana, 2016). It means that lecturers and teaching staff must have good communication skills in handling complaints from students, must be patient, firm, and have uniformity of information provided to students. In addition, lecturers and teaching staff must be responsive in handling complaints from students, lest complaints become wild balls and backfire for Unisba. Lecturers and teaching staff must open themselves to establish communication with students,

TABLE 11. Technology Indikator

\begin{tabular}{|c|c|c|c|c|c|c|c|}
\hline No. & Statement & $\begin{array}{l}\mathrm{SS} \\
\%\end{array}$ & $\begin{array}{c}\mathrm{S} \\
\%\end{array}$ & $\begin{array}{c}\text { TAP } \\
\%\end{array}$ & $\begin{array}{l}\mathrm{TS} \\
\%\end{array}$ & $\begin{array}{c}\mathrm{STS} \\
\%\end{array}$ & $\begin{array}{l}\text { TOTAL } \\
\text { SCORE }\end{array}$ \\
\hline 1. & Unisba e-lecture system makes it easy to study online & 12.9 & 66.7 & 12.9 & 5.3 & 2.3 & 100 \\
\hline 2. & Unisba e-lecture system is easy to operate & 12.1 & 65.2 & 12.9 & 5.3 & 2.3 & 100 \\
\hline 3. & Unisba e-lecture system often experience troubles & 39.4 & 50.8 & 5.3 & 3.8 & 0.8 & 100 \\
\hline 4. & $\begin{array}{l}\text { Unisba e-lecture system facilitates the implementation } \\
\text { of midterm and final exams }\end{array}$ & 14.4 & 49.2 & 18.9 & 13.6 & 3.8 & 100 \\
\hline 5. & $\begin{array}{l}\text { Material facilities, discussion forums, assignments, } \\
\text { and quizzes can represent face-to-face lectures }\end{array}$ & 12.1 & 47.0 & 14.4 & 21.2 & 5.3 & 100 \\
\hline 6. & $\begin{array}{l}\text { Unisba e-lecture system is needed to improve the } \\
\text { quality of its lectures }\end{array}$ & 21.2 & 69.7 & 6.8 & 1.5 & 0.8 & 100 \\
\hline 7. & $\begin{array}{l}\text { Unisba must improve the quality of the e-lecture } \\
\text { system }\end{array}$ & 75.8 & 20.5 & 2.3 & 0.8 & 0.8 & 100 \\
\hline 8. & $\begin{array}{l}\text { The university, faculties, lecturers, and teaching staff } \\
\text { have easy-to-contact communication media }\end{array}$ & 9.1 & 65.9 & 16.3 & 7.6 & 0.8 & 100 \\
\hline 9. & $\begin{array}{l}\text { The university, faculties, lecturers, and teaching staff } \\
\text { use social media to communicate with students }\end{array}$ & 9.8 & 71.2 & 12.1 & 6.1 & 0.8 & 100 \\
\hline
\end{tabular}

$\mathrm{SS}=$ Strongly Agree, $\mathrm{S}=$ Agree, $\mathrm{TAP}=$ No Opinion, $\mathrm{TS}=$ Disagree, $\mathrm{STS}=$ Strongly Disagree 
lest they cannot be contacted by students. Lecturers and teaching staff must be able to deal with various stressful situations and conditions even under controlled conditions. As the word of Allah in Surah Al-Imran (3): 159 which means: "It was by the Mercy from Allah that you were lenient with them. Had you been rough and harsh-hearted, they would have dispersed from around you..."(Trimanah \& Wulandari, 2018).

\section{Technology Indicator}

Technology indicator consists of measuring instruments for the e-lecture system and communication media. The remote-learning through e-lecture system becomes effective and solution during teh pandemic (Afriliana et al., 2021). This lecture system is represented by questions no. 1 - 7; some respondents agreed $(50.8 \%)$ that Unisba e-lecture system often experienced troubles, facilitated the implementation of the midterm and final exams, and the facilities of e-lectures could represent face-toface lectures. Most of the respondents agreed that the e-lecture system made lectures easier, easy to operate, and able to improve the quality of lectures. The most interesting part of the respondents' answers is that $75.8 \%$ strongly agreed that Unisba should improve the quality of the e-lecture system. Unisba's e-lecture system must be user friendly, easy to use, uncomplicated and easily accessible. For measuring communication media, most of the respondents stated that the university, faculties, lecturers, and teaching staff had communication media and social media to communicate with students.

The regression method used was the enter method, which was to enter all predictors at once.

TABLE 12

Variables Entered/Removed ${ }^{\mathrm{a}}$

\begin{tabular}{llll}
\hline Model & $\begin{array}{l}\text { Variables } \\
\text { Entered }\end{array}$ & $\begin{array}{l}\text { Variables } \\
\text { Removed }\end{array}$ & Method \\
\hline 1 & Var_X3 & & Enter \\
& Technology & & \\
\hline
\end{tabular}

a. Dependent Variable: Var_Y_Satisfaction

b. All requested variables entered.

In the adjusted R Square column, the score is 0.315 . This figure shows how much the independent variables are able to explain changes in the dependent variables. The value of $\mathrm{R}$ Square means that $32.0 \%$ change in the $\mathrm{Y}$ variable (Student Satisfaction) is influenced by the X3 Variable (Information Technology Indicator). The variation of the independent variables used in the

TABLE 13

ANOVA $^{\mathrm{a}}$

\begin{tabular}{clccccc}
\hline Model & & Sum of & Df & Mean Square & F & Sig. \\
& & Squares & & & & \\
\hline \multirow{2}{*}{1} & Regression & 790,210 & 1 & 790,210 & 61,255 & $.000^{\mathrm{b}}$ \\
& Residual & 1677.032 & 130 & 12,900 & & \\
& Total & 2467.242 & 131 & & & \\
\hline
\end{tabular}

a. Dependent Variable: Var_Y_Satisfaction

b. Predictors: (Constant), Var_X3_Technology

TABLE 14

Coefficients $^{\mathrm{a}}$

\begin{tabular}{clccccc}
\hline Model & \multicolumn{2}{c}{$\begin{array}{c}\text { Unstandardized } \\
\text { Coefficients }\end{array}$} & $\begin{array}{c}\text { Standardized } \\
\text { Coefficients }\end{array}$ & T & Sig. \\
& B & Std. Error & Beta & & \\
\hline \multirow{2}{*}{1} & (Constant) & 6,031 & 3,088 & & 1,953 & .053 \\
& Var_X3_Technology & .616 & .079 & .566 & 7,827 & .000 \\
\hline
\end{tabular}

a. Dependent Variable: Var_Y_Satisfaction 
X3 model (Information Technology) is able to explain $32 \%$ of the variation in the dependent variable. Meanwhile, the remaining $68 \%$ is influenced or explained by other variables that are not included in this research model.

In the TABLE 13, the F-value is 61.255 and the significance is 0.000 . The conclusion is that the $\mathrm{X} 3$ variable (Information Technology) has an influence on $\mathrm{Y}$ variable.

TABLE 14 shows that the t-value of the X3 variable is 7.827 and the significance value is 0.000 . It means that the $\mathrm{X} 3$ variable (Information Technology) has a significant influence on the $\mathrm{Y}$ variable (Student Satisfaction).

The description above shows that the regression equation for the influence of the X3 variable (Information Technology) on the Y variable (Student Satisfaction) can be described as follows:

$$
Y=6.031+0.616 \times 3
$$

\section{Regression Equation Analysis:}

If the X3 variable (Information Technology) increases, the $\mathrm{Y}$ variable (Student Satisfaction) does the same. The most influencing indicators are: e-lecture system and communication media in service communication.

It means that the indicators of the e-lecture system and communication media in service communication during a pandemic affect student satisfaction. The study results show that the use of Moodlebased e-learning is very appropriate to use during the Covid-19 pandemic, to overcome conventional learning activities (Sara et al., 2020).

Technology was introduced to assist, accelerate and optimize human and process factors in CRM activities. In the context of this research, technology helps lecturers, teaching staff, and students to conduct lectures and provide online services, especially during the Covid-19 pandemic. Teaching and learning activities are forced to quickly transform into online. While not all colleges are ready to do online learning. However, it turns out that this actually increases the creativity of universities to ensure that teaching and learning activities must continue in the midst of unpreparedness. Unisba must optimize the use of advanced communication technology to improve the performance of lecturers and educators (Effendi \& Setiadi, 2021). With the pandemic, Unisba is required to use online technology in providing services to students; from lectures, sessions, boarding schools, libraries, graduations, and others. In addition, the role of technology in CRM is to build student databases ranging from operating systems to transactions.

Information technology used by lecturers, teaching staff and students must have the ability to 'self-service' (Hamidin, 2008). Technologies such as Unisba's e-lecture and e-payment systems can be used easily and independently. At the beginning of the use of technology, universities or faculties must provide training so that users can immediately use the technology. In addition, lecturers and teaching staff must adapt to technology, where technology is currently a unit in learning/lectures and services (Adisel \& Prananosa, 2020). The existence of science and technology further improves the quality of learning, so that lecturers are required to be able to use technology in accordance with the developments and demands of the times. At the time of the Prophet Muhammad SAW, humans were familiar with teaching and learning activities, he taught knowledge to his companions with 'media' as a means of delivering material for Islamic teachings. (Zainuri, 2018). In addition, lecturers must have professional competence who always improve and develop academic qualifications and competencies on an ongoing basis in line with the development 
of science and technology.

\section{CONCLUSION}

Based on the results of questionnaires, site observations, and statistical test results, the researchers concluded that there is a significant influence of Customer Relationship Management during the COVID-19 pandemic on Unisba student satisfaction. The results of the hypothesis test show that t-count from the aspects of people, process, and technology is greater than $\mathrm{t}$-table ( $\mathrm{t}$-count $>\mathrm{t}$-table). This shows that aspects of people, processes, and technology have a significant influence on student satisfaction of Unisba.

Due to the limitations and shortcomings in this study, next researchers are expected to be able to expand the object of research in several higher institutions so that research results can contribute to service communication in universities. In addition, researchers also suggest using qualitative methods and in-depth research so as to produce a service communication model in universities.

\section{REFERENCES}

Adisel, A., \& Prananosa, A. G. (2020). Penggunaan Teknologi Informasi dan Komunikasi dalam Sistem Manajemen Pembelajaran pada Masa Pandemi Covid 19. Journal Of Administration and Educational Management (ALIGNMENT), 3(1). https://doi.org/10.31539/alignment. v3i1.1291

Afriliana, I., Indrianto, J., \& Kusuma, A. C. (2021). Pemanfaatan Teknologi Informasi guna Peningkatan Kemampuan Pendidik untuk Model Pembelajaran Jarak Jauh. 10(02), 266-274. https://doi.org/https://doi. org/10.22236/solma.v10i2.6510

Bajari, A. (2015). Metode penelitian Komunikasi; Prosedur, Trend \& Etika. Simbioasa Rekatama Media.
Bungin, B. (2017). Metode Penelitian Kuantitatif. Kencana Prenada Media Group. Jakarta.

Effendi, M. R., \& Setiadi, E. (2021). Model of Development of Ruhul Islam In Bandung Islamic University. MIMBAR : Jurnal Sosial Dan Pembangunan, 37(1). https://doi. org/10.29313/mimbar.v37i1.7689

Hamidin, D. (2008). Model customer relationship management (CRM) di institusi pendidikan. Seminar Nasional Aplikasi Teknologi Informasi (SNATI) Vol.1 No.1.

Indriyani, S., \& Mardiana, S. (2016). Pengaruh Penanganan Keluhan (Complaint Handling) Terhadap Kepercayaan Dan Komitmen Mahasiswa Pada Perguruan Tinggi Swasta Di Bandar Lampung. Jurnal Bisnis Darmajaya, 2(1), 1-13.

Kasmir. (2017). Customer Service Excellent : Teori dan Praktik. PT Rajagrafindo Persada.

Kriyantono, R. (2014). Teori public relations perspektif barat dan lokal: Aplikasi penelitian dan praktik. Kencana.

Madiawati, P. N., Pradana, M., \& Sulistijono, S. (2020). The Importance of Organizational Commitments and Performance: Studies of Corporate University in West Java. MIMBAR : Jurnal Sosial Dan Pembangunan, 36(2). https://doi.org/10.29313/ mimbar.v36i2.5941

Rustanta, A., \& Setyawati, K. (2019). Hubungan Layanan Komunikasi terhadap Kepuasan Mahasiswa. Jurnal Ilmu Komunikasi Dan Bisnis , 4(2).

Saleh, A. M. (2010). Public Service Communication. Universitas Muhammadiyah Malang.

Sampurno, M. B. T., Kusumandyoko, T. C., \& Islam, M. A. (2020). Budaya Media Sosial, Edukasi Masyarakat, dan Pandemi COVID-19. SALAM: Jurnal Sosial Dan Budaya Syar-I, 7(5). https://doi.org/10.15408/sjsbs. v7i5.15210

Sara, K., Witi, F. L., \& Mude, A. (2020). Implementasi E-Learning Berbasis Moodle di Masa Pandemi Covid 
19. Journal Of Administration and Educational Management (ALIGNMENT), 3(2). https://doi. org/10.31539/alignment.v3i2.1813

Suryana, A., Zein, D., Sumartias, S., \& Gemiharto, I. (2019). Pengaruh Strategi Komunikasi Pemasaran, Budaya Organisasi, Karakteristik Individu Inovatif Dan Komitmen Organisasional Terhadap Kinerja Usaha Kecil Dan Menengah. Jurnal Manajemen Komunikasi, 3(2). https://doi.org/10.24198/jmk. v3i2.20754

Tjia, M., \& Fitriani, D. R. (2019). Pengaruh Motif Selfie Terhadap Keterbukaan Diri Generasi Milenial. Mediator: Jurnal Komunikasi, 12(2). https://doi. org/10.29313/mediator.v12i2.5037

Trimanah, T., \& Wulandari, D. (2018). Prinsip Public Relations dalam Ajaran Islam
Menurut Persepsi Anggota Perhumas Jawa Tengah. Mediator: Jurnal Komunikasi, 11(1). https://doi. org/10.29313/mediator.v11i1.3171

Wiwitan, T., \& Yulianita, N. (2017). Strategi Marketing Public Relations Perguruan Tinggi Islam Swasta: Peluang dan Tantangan di Era MEA. Mediator: Jurnal Komunikasi, 10(1). https://doi.org/10.29313/mediator. v10i1.2672

Wuri, J. (2021). Kinerja Pegawai Dalam Pelayanan Publik Di Era Covid-19 (Studi Di Kecamatan Langowan Barat Kabupaten Minahasa). Jurnal Politico, 21(1).

Zainuri, A. (2018). Media Pembelajaran dalam Pandangan Islam. MedinaTe : Jurnal Studi Islam, 14(1), 1-17. https://doi.org/10.19109/medinate. v14i1.2351 